\title{
PENINGKATAN KEMAMPUAN KOGNITIF MELALUI PERMAINAN PECAH TELUR PADA ANAK KELOMPOK A DI RA SHODRUL ULUM AL-CHOLIL BRONGKAL PAGELARAN-MALANG
}

\author{
Yulia Zamzami ${ }^{1}$, Ratih Permata Sari ${ }^{2}$ \\ Program Studi Pendidikan Islam Anak Usia Dini,Fakultas Tarbiyah, \\ Institut Agama Islam Al-Qolam Malang \\ ratih@alqolam.ac.id
}

\section{Info Artikel}

Riwayat Artikel

Diterima :

10 Oktober 2019

Disetujui :

10 November 2019

\section{Kata Kunci :}

Kemampuan Kognitif, Permainan Pecah Telur

\begin{abstract}
ABSTRAK
Abstract: The process of increasing children's cognitive abilities in learning is very important to be developed through the process of game activities. The purpose of this research is to describe the improvement of cognitive abilities by using the game of breaking eggs in group A children and to describe the application of the game of breaking eggs that can improve cognitive abilities in children of group A. This research uses a class action research (Action Research) using two cycles applied in RA children in group A. The results of the study in the first cycle showed an increase in cognitive abilities in recognizing the concept of numbers but still had not reached maximum results with a percentage of $43.13 \%$. Meanwhile, the results of research in the second cycle have shown the development of cognitive abilities in recognizing the concept of numbers with a percentage of $79.40 \%$. The final results of an average increase between the two cycles reached $36.27 \%$. The research can be concluded that the increase between the two cycles is influenced by the presence of a broken egg in the form of a game concept in the cognitive learning process of early childhood.
\end{abstract}

Abstrak: Proses peningkatan kemampuan kognitif anak dalam pembelajaran sangat penting dikembangan melalui proses aktivitas permainan. Tujuan penelitian untuk mendeskripsikan peningkatkan kemampuan kognitif dengan menggunakan permainan pecah telur pada anak kelompok A dan untuk mendeskripsikan penerapan permainan pecah telur yang dapat meningkatkan kemampuan kognitif pada anak kelompok A. Penelitian ini menggunakan penelitian tindakan kelas (Action Research) dengan menggunakan dua siklus yang di terapkan pada anak RA kelompok A. Hasil penelitian pada siklus I menunjukkan adanya peningkatan kemampuan kognitif dalam mengenal konsep bilangan namun masih belum mencapai hasil yang maksimal dengan prosentase 43,13\%. Sedangkan, hasil penelitian pada siklus II sudah menunjukkan pengembangan kemampuan kognitif dalam mengenal konsep bilangan dengan prosentase $79,40 \%$. Hasil akhir rata-rata peningkatan antar kedua siklus mencapai $36,27 \%$. Penelitian dapat disimpulkan bahwa peningkatan antar kedua siklus dipengaruhi adanya media pecah telur yang di bentuk pada konsep permainan dalam proses pembelajaran kognitif anak usia dini. 


\section{PENDAHULUAN}

Pendidikan anak usia dini merupakan peletak dasar pertama dan utama dalam pengembangan pribadi anak, baik berkaitan dengan karakter, kemampuan fisik, kognitif, bahasa, seni, sosial emosional, spiritual, disiplin diri, konsep diri maupun kemandirian. ${ }^{1}$ Oleh karena itu, dalam memberikan layanan pendidikan, perlu dipahami karakteristik perkembangan serta cara-cara anak belajar dan bermain.

Mengingat begitu pentingnya anak dalam urusan pendidikan, dan pentingnya anak usia dini dalam perkembangan manusia secara keseluruhan, maka pendidikan anak usia dini atau PAUD perlu diberikan melalui berbagai pemberian rangsangan untuk membantu pertumbuhan dan perkembangan jasmani dan rohani anak agar lebih siap memasuki pendidikan yang selnjutnya. Dalam hal ini, pendidikan memegang bagian yang sangat penting dan menentukan bagi sejarah perkembangan anak selanjutnya serta menjadi pondasi perkembangan kepribadiannya. Anak yang sudah mendapatkan pendidikan sejak usia dini akan dapat meningkatkan kesehatan serta kesejahteraan fisik dan mental, yang akan berpengaruh pada peningkatan motivasi anak, prestasi dan kinerjanya, sehingga anak akan lebih mampu untuk mandiri dan mengoptimalkan berbagai potensinya. Pengembangan potensi anak ada beberapa perkembangan yang harus dicapai diantaranya perkembangan kognitif, bahasa, fisik motorik, sosial emosional dan pembiasaan sehari-hari. ${ }^{2}$ Untuk mencapai semua aspek perkembangan perlu dicapainya tujuan pendidikan anak usia dini (PAUD). Peneliti akan mencoba meningkatkan salah satu bidang pengembangan yaitu kognitif.

Kognitif adalah suatu proses berfikir, yaitu kemampuan individu untuk menghubungkan, menilai dan mempertimbangkan suatu kejadian atau peristiwa. ${ }^{3}$ Proses kognitif ini berhubungan dengan tingkat kecerdasan individu (anak) yang ditandai dengan berbagai minat terutama kepada ide-ide dan belajar. Menurut Piaget, perkembangan kognitif merupakan suatu proses genetik, yaitu suatu proses yang didasarkan atas mekanisme biologis perkembangan sistem syaraf. Dengan makin bertambahnya umur seseorang, maka makin komplekslah susunan sel syarafnya dan makin meningkat pula kemampuannya. Proses belajar akan terjadi jika mengikuti tahap-tahap asimilasi, akomodasi, dan ekuilibrasi (penyeimbangan antara asimilasi dan akomodasi). Piaget membagi tahap-tahap perkembangan kognitif menjadi empat, yaitu: Tahap sensori motorik (umur 0-2 tahun), Tahap pra operasional (umur 2-7/8 tahun), Tahap operasional konkret (umur 7/8-11/12 tahun), Tahap operasional formal (umur 11/12-18 tahun).

\footnotetext{
${ }^{1}$ Mansur (2014). Pendidikan Anak Usia Dini Dalam Islam. Yogyakarta : Pustaka Belajar.

${ }^{2}$ Asmawati,. L. (2014). Perencanaan Pembelajaran PAUD. Bandung : Remaja Rosdakarya.

${ }^{3}$ Sari,. R.P. (2017). Buku Ajar Perkembangan Kognitif Anak Usia Dini. Malang : IAI AL-Qolam.
} 
Tahap perkembangan kognitif anak RA/TK usia 4-5 tahun tergolong tahap praoperasional. Praoperasional adalah tahap perkembangan kognitif anak pada usia dua - tujuh (2-7) tahun. Ciri-ciri yang dapat diamati pada periode ini, yaitu anak sudah dapat menggunakan simbol-simbol untuk menyatakan objek dunia. Pemikirannya masih egosentris dan sentrasi. Egosentris ialah sifat keakuan. Artinya, setiap benda yang dipegang atau dibawa oleh anak dianggap miliknya dan orang lain tidak boleh memegang, mengambil, atau meminjamnya. Adapun sentrasi merupakan sikap anak yang memfokuskan pada satu titik atau benda yang dianggap menarik bagi dirinya. Idealnya untuk mengembangkan perkembangan kognitif anak dari segi mengenal konsep bilangan maka perlu dikembangkan pengenalan konsep bilangan dengan indikator kognitif meliputi menunjuk angka 1 sampai 10, meniru angka 1 sampai 10, menghubungkan atau memasangkan angka dengan benda-benda sampai 10, membilang dengan menunjuk benda (mengenal konsep bilangan dengan benda-benda) sampai 10, menunjukkan urutan benda untuk bilangan sampai 10 dan membuat urutan angka 1 sampai 10 dengan benda.

Pentingnya pemahaman tentang konsep bilangan pada anak yang akan dapat memahami cara menghitung benda secara riil. Sebaliknya jika anak tidak dikenalkan dengan konsep bilangan maka anak akan kesulitan dalam memahami angka-angka sebab anak tidak bisa menyebutkan benda atau angka dengan cara abstrak. Seharusnya anak kelompok A sudah mampu mengenal angka/bilangan 1 sampai 10.

Hasil observasi atau pengamatan di kelompok A ternyata sebagian anak dalam menghitung terbukti dari 17 siswa yang terdiri dari 8 laki-laki dan 9 perempuan ada 5 anak yang sudah dapat menghitung lancar, sedangkan yang 12 anak belum dapat menghitung dengan lancar, cara menghitung anak masih loncatloncat belum urut, ada sebagian anak yang dapat berhitung dari 1 sampai 10 akan tetapi ketika anak disuruh untuk menunjukkan, menirukan dan mengurutkan angka 1 sampai 10 anak masih bingung dan kadang ada anak yang masih terbalik dalam menulis angka. Semua itu dikarenakan metode yang digunakan guru kurang menarik bagi anak. Media atau alat peraga yang digunakan hanya menggunakan jari sehingga dengan media yang kurang menarik anak terlihat kurang berkesan sehingga anak merasa bosan dan jenuh dalam menghitung.

Melihat kondisi yang seperti itu penulis mencoba meningkatkan kemampuan kognitif anak dalam mengenal angka melalui permainan pecah telur. Melalui permainan pecah telur diharapkan anak mampu mengembangkan potensi yang dimilikinya terutama dalam menghitung. Dengan permainan pecah telur memberi banyak peluang kepada anak untuk melakukan kegiatan berhitung sambil memasangkan 2 bagian permainan pecah telur menjadi 1 telur utuh sesuai dengan benda yang sudah dihitung dengan angka yang melambangkannya.

Permainan pecah telur adalah permainan yang terbuat dari kertas karton yang dibentuk bulat kemudian dibelah menjadi dua bagian sesuai pola. Jika disatukan akan menjadi satu telur utuh. Permainan ini dinamakan pecah telur karena 
permainan ini berbentuk bulat menyerupai telur dan pecah karena dibelah menjadi dua bagian. Permainan Pecah telur ini memiliki jenis pembelajaran visual berupa gambar yang menyangkut dengan indra penglihatan. Permainan pecah telur merupakan permainan yang terbuat dari kertas karton yang dibentuk lingkaran, yang dibentuk pola zig-zag ditengahnya dan digunting menjadi dua bagian, kemudian ditempelkan kertas lipat yang berwarna-warni. Bagian pertama diberi gambar angka, sedangkan bagian yang lainnya diberi sejumlah gambar benda yang menyatakan sesuai dengan angka yang melambangkannya pada bagian permainan pecah telur yang pertama. Permainan pecah telur juga merupakan alat permainan edukatif indoor yaitu APE yang berada di dalam ruangan yang bercirikan ukuran lebih kecil dan ringan, digunakan di dalam ruangan, menunjang kognitif dan pembelajaran area. Selain itu, media pecah telur juga termasuk dalam kategori APE modern karena ditemukan, diciptakan, dan dikembangkan pada masa kini sesuai dengan perkembangan zaman. ${ }^{4}$

Tujuan Penelitian ini adalah Untuk mendeskripsikan peningkatkan kemampuan kognitif dengan menggunakan permainan pecah telur pada anak kelompok A di RA dan Untuk mendeskripsikan penerapan permainan pecah telur yang dapat meningkatkan kemampuan kognitif pada anak kelompok A di RA.

\section{METODE}

Penelitian ini menggunakan rancangan penelitian tindakan kelas (PTK). Penentuan rancangan penelitian didasarkan pada keinginan peneliti untuk meningkatkan kemampuan kognitif anak dalam mengenal konsep bilangan melalui permainan pecah telur. Menurut Suharsimi Arikunto yang dikutip oleh Suyadi, Penelitian Tindakan Kelas (PTK) terdiri dari tiga kata meliputi penelitian, tindakan, dan kelas. Dari ketiga unsur pengertian tersebut, dapat disimpulkan yang dimaksud dengan Penelitian Tindakan Kelas (PTK) adalah pencermatan dalam bentuk tindakan terhadap kegiatan belajar yang sengata dimunculkan dan terjadi dalam sebuah kelas secara bersamaan. ${ }^{5}$ Desain Penelitian Tindakan Kelas (PTK) menurut Kemmis \& Mc Taggart dalam Wardhani menyatakan dari model desain Penelitian Tindakan Kelas (PTK) yang dikemukakan secara global terdiri atas empat komponen, yaitu perencanaan (planning), pelaksanaan tindakan (action), observasi (observation), dan refleksi (reflection), ${ }^{6}$ kemudian berputar - terjadi perbaikan atau peningkatan yang diharapkan. Penelitian ini dilaksanakan selama enam kali pertemuan.

\footnotetext{
${ }^{4}$ Fadlillah,. M. (2017). Bermain Dan Permainan Anak Usia Dini. Jakarta : KENCANA.

${ }^{5}$ Arikunto,. S. (2002). Prosedur Penelitian. Jakarta : Rineka Cipta.

${ }^{5}$ Wardhani,. IGAK. (2014). Penelitian Tindakan Kelas. Jakarta : Universitas Terbuka.
} 
Lokasi penelitian di RA Shodrul Ulum Al-Cholil Brongkal Kecamatan Pagelaran Kabupaten Malang. Subyek penelitian ini adalah siswa kelompok A yang terdiri dari 3 kelas A1, A2, dan A3 sebanyak 52 anak dan yang diambil sampel hanya 1 kelas saja yaitu kelas A1 sebanyak 17 anak.

Teknik pengumpulan data utama yang digunakan dalam penelitian ini adalah observasi. observasi dilakukan untuk mengumpulkan data dalam praktik pembelajaran yang dilakukan oleh guru dan peneliti untuk merekam segala gejala yang terlihat dalam proses pembelajaran, seperti ketepatan anak dalam mengenal konsep bilangan yaitu: menunjuk angka, meniru dengan menulis angka, menghubungkan atau memasangkan benda-benda dengan angka yang melambangkannya, membilang dengan menunjuk benda, menunjuk urutan benda dan membuat urutan angka dalam permainan pecah telur.

Penelitian ini menggunakan teknik analisis deskriptif kualitatif dan kuantitatif. Menurut Anas Sujiono (2011) bahwa data analisis deskriptif kualitatif dan kuantitatif data yang berbentuk angka. Data kuantitatif ini diolah berdasarkan data hasil pengamatan melalui observasi aktivitas anak. Kriteria keberhasilan dalam penelitian ini dinyatakan berhasil jika kemampuan kognitif anak mencapai $75 \%$ atau berkembang sesuai harapan (BSH).

\section{HASIL DAN PEMBAHASAN}

Sebelum melaksanakan penelitian, dilakukan observasi terlebih dahulu pada perkembangan kognitif anak terutama pada konsep mengenal lambang bilangan. Hasil observasi diperoleh pada saat guru mengajak anak untuk melakukan kegiatan berhitung. Guru mempersilahkan anak melakukan kegiatan berhitung 1 sampai 10 dengan cara menulis soal penjumlahan di papan tulis sesuai dengan jumlah anak. Lalu guru memanggil anak secara bergantian untuk maju kedepan dan menjawab soal di papantulis. Dalam kegiatan tersebut dapat dikatakan kemampuan anak masih belum berkembang dengan baik, banyak anak yang masih membutuhkan bantuan guru dalam prmbelajaran. Pengukuran kemampuan kognitif dilakukan dengan observasi pra tindakan, peneliti menggunakan lembar observasi yang sudah disiapkan untuk memperoleh data peningkatan kemampuan kognitif pra tindakan.

Perencanaan tindakan disusun meliputi (1) Menyusun rencana pelaksanaan pembelajaran harian (RPPH), yang digunakan selama pembelajaran dalam satu hari bersama guru kelas. (2) Menyusun dan mempersiapkan lembar observasi pelaksanaan pada setiap pertemuan yang dapat mengetahui kemampuan kognitif melalui permainan pecah telur. (3) Menyusun dan mempersiapkan sarana dan media dalam permainan pecah telur yang akan digunakan saat penelitian. Dalam Penelitian ini berupa permainan pecah telur. (4) Mempersiapkan lembar wawancara. (5) Mempersiapkan lembar observasi dan penilaian. Siklus I dilaksanakan selama 6 kali pertemuan. 
Hasil penelitian menunjukkan bahwa ada peningkatan pada kemampuan kognitif anak, hal ini dapat dilihat dari hasil observasi pada beberapa kegiatan yaitu: anak dapat menunjuk, meniru, menghubungkan atau memasangkan angka dengan benda-benda, membilang dengan menunjuk benda, menunjuk urutan benda untuk bilangan, dan membuat urutan angka dengan benda mulai dari 1 sampai 10 . Perkembangan rata-rata anak kelompok A dapat dilihat pada tabel 4.1, sebagai berikut:

\begin{tabular}{|c|c|c|c|c|}
\hline \multirow[t]{2}{*}{ No } & \multirow[t]{2}{*}{ Aspek yang diamati } & \multicolumn{3}{|c|}{ Rata-rata Indikator Keberhasilan } \\
\hline & & $\mathbf{M}$ & TM & Ket. \\
\hline 1 & Menunjuk angka 1 sampai 10 & $52,94 \%$ & $47,05 \%$ & MB \\
\hline 2 & Meniru angka 1 sampai 10 & $47,05 \%$ & $52,94 \%$ & $\mathrm{MB}$ \\
\hline 3 & $\begin{array}{l}\text { Menghubungkan } \\
\text { memasangkan angka } \\
\text { benda-benda sampai } 10\end{array}$ & $35,29 \%$ & $64,70 \%$ & $\mathrm{BB}$ \\
\hline 4 & $\begin{array}{l}\text { Mebilang dengan menunjuk benda } \\
\text { (mengenal konsep angka dengan } \\
\text { benda-benda) sampai } 10\end{array}$ & $41,17 \%$ & $58,82 \%$ & $\mathrm{MB}$ \\
\hline 5 & $\begin{array}{l}\text { Menunjuk urutan benda untuk } \\
\text { bilangan sampai } 10\end{array}$ & $47,05 \%$ & $52,94 \%$ & $\mathrm{MB}$ \\
\hline 6 & $\begin{array}{l}\text { Membuat urutan angka } 1 \text { sampai } \\
10 \text { dengan benda }\end{array}$ & $35,29 \%$ & $64,70 \%$ & $\mathrm{BB}$ \\
\hline & Rata-rata & $43,13 \%$ & $56,85 \%$ & MB \\
\hline
\end{tabular}

Berdasarkan paparan data pada tabel 4.1 di atas terlihat bahwa pada siklus I peningkatan kemampuan kognitif melalui permainan pecah telur dengan indikator menunjuk angka 1 sampai 10 mencapai nilai 52,94\%, meniru angka 1 sampai 10 mencapai nilai 47,05 \%, menghubungkan atau memasangkan angka dengan bendabenda sampai 10 mencapai 35,29\%, membilang dengan menunjuk benda sampai 10 mencapai nilai 41,17 \%, menunjuk urutan benda untuk bilangan sampai 10 mencapai nilai 47,05\% dan membuat urutan angka 1 sampai 10 dengan benda mencapai nilai 35,29\%. Sehingga nilai rata-rata kemampuan kognitif melalui permaianan pecah telur secara keseluruhan adalah 43,13\%.

Hasil refleksi siklus I masih perlu perbaikan pada siklus II karena pada siklus I masih belum mencapai indikator keberhasilan yang diharapkan. Pelaksnaan siklus II perlu mengganti warna pada bagian-bagian permainan pecah telur agar anak dapat menyatukan 2 bagian permainan pecah telur dengan cara berhitung, mengulang kembali kegiatan semua kegiatan dari awal yaitu menyatukan 2 bagian permainan pecah telur menjadi 1 telur utuh dengan cara menunjuk dan mengurut hitungan benda 1 sampai 10 kemudian dihubungkan dengan angka yang melambangkannya, dan anak diberi mainan lain sambil menunggu giliran bermain permainan pecah telur.

\footnotetext{
${ }^{7}$ Tabel 1. Hasil Observasi Keseluruhan Siklus I Peningkatan Kemampuan kognitif pada anak kelompok A melalui permainan pecah telur.
} 
Sebelum melakukan kegiatan pembelajaran pada siklus II disusun perencanaan terlebih dahulu. Perencanaan ini sama halnya dengan siklus I yang dibutuhkan antara lain: (1) Menyusun rencana pelaksanaan pembelajaran harian (RPPH), yang digunakan pembelajaran dalam satu hari bersama guru kelas. (2) Menyusun dan mempersiapkan lembar observasi pelaksanaan pada setiap pertemuan yang dapat mengetahui kemampuan kognitif melalui permainan pecah telur. (3) Menyusun dan mempersiapkan sarana dan media dalam permainan pecah telur yang akan digunakan saat penelitian. Dalam Penelitian ini berupa permainan pecah telur. (4) Mempersiapkan lembar observasi dan penilaian.

Hasil penelitian pada silus II menunjukkan adanya peningkatan pada kemampuan kognitif anak kelompok A dalam mengenal konsep bilangan yang distimulasi dengan menggunakan permainan pecah telur. Perkembangan rata-rata anak kelompok A dapat dilihat pada tabel sebagai berikut.

Tabel 4.2 Hasil Observasi Keseluruhan Siklus II Peningkatan Kemampuan kognitif pada anak kelompok A melalui permainan pecah telur di RA Shodrul Ulum Al-Cholil Brongkal Pagelaran Malang. ${ }^{8}$

\begin{tabular}{|c|c|c|c|c|}
\hline \multirow[t]{2}{*}{ No } & \multirow[t]{2}{*}{ Aspek yang diamati } & \multicolumn{3}{|c|}{ Rata-rata Indikator Keberhasilan } \\
\hline & & $\mathbf{M}$ & TM & Ket. \\
\hline 1 & Menunjuk angka 1 sampai 10 & $82,35 \%$ & $17,64 \%$ & BSB \\
\hline 2 & Meniru angka 1 sampai 10 & $76,47 \%$ & $23,52 \%$ & BSH \\
\hline 3 & $\begin{array}{l}\text { Menghubungkan atau } \\
\text { memasangkan angka dengan } \\
\text { benda-benda sampai } 10\end{array}$ & $64,70 \%$ & $35,29 \%$ & $\mathrm{BSH}$ \\
\hline 4 & $\begin{array}{l}\text { Mebilang dengan menunjuk } \\
\text { benda (mengenal konsep angka } \\
\text { dengan benda-benda) sampai } \\
10\end{array}$ & $88,23 \%$ & $11,76 \%$ & BSB \\
\hline 5 & $\begin{array}{l}\text { Menunjuk urutan benda untuk } \\
\text { bilangan sampai } 10\end{array}$ & $94,11 \%$ & $5,88 \%$ & BSB \\
\hline 6 & $\begin{array}{l}\text { Membuat urutan angka } 1 \\
\text { sampai } 10 \text { dengan benda }\end{array}$ & $70,58 \%$ & $29,41 \%$ & $\mathrm{BSH}$ \\
\hline & Rata-rata & $79,40 \%$ & $20,58 \%$ & BSH \\
\hline
\end{tabular}

Berdasarkan paparan data pada tabel 4.2 di atas terlihat bahwa pada siklus II peningkatan kemampuan kognitif melalui permainan pecah telur dengan indikator menunjuk angka 1 sampai 10 mencapai nilai 82,35 \%, meniru angka 1 sampai 10 mencapai nilai 76,47 \%, dan menghubungkan atau memasangkan angka dengan benda-benda sampai 10 mencapai 64,70\%, membilang dengan menunjuk benda sampai 10 mencapai nilai $88,23 \%$, menunjuk urutan benda untuk bilangan sampai 10 mencapai nilai 94,11\% dan membuat urutan angka 1 sampai 10 dengan benda mencapai nilai $70,58 \%$. Sehingga nilai rata-rata kemampuan kognitif melalui permaianan pecah telur secara keseluruhan mencapai 79,40\%.

\footnotetext{
${ }^{8}$ Hasil Observasi Keseluruhan Siklus II Peningkatan Kemampuan kognitif pada anak kelompok A melalui permainan pecah telur di RA Shodrul Ulum Al-Cholil Brongkal Pagelaran Malang.
} 
Hasil penelitian yang dilakukan pada siklus II hasil proses pelaksanaan pembelajaran kognitif melalui aktivitas bermain permaianan pecah telur untuk meningkatkan kemampuan anak dalam mengenal angka pada siklus II menunjukkan peningkatan dibandingkan pada siklus I. Hal ini dapat dilihat dari perbandingan presentase hasil observasi dan penilaian secara keseluruhan kegiatan pembelajaran pada siklus I dan siklus II, sebagai berikut:

Tabel 4.3 Perbandingan Hasil Observasi Siklus I dan Siklus II Peningkatan Kemampuan kognitif pada anak kelompok A melalui permainan pecah telur ${ }^{9}$

\begin{tabular}{|c|l|c|c|c|}
\hline \multirow{2}{*}{ No } & \multicolumn{2}{|c|}{ Aspek yang diamati } & \multicolumn{3}{|c|}{ Rata-rata Indikator Keberhasilan } \\
\cline { 2 - 5 } & Siklus I & Siklus II & Peningkatan \\
\hline 1 & $\begin{array}{l}\text { Menunjuk angka 1 sampai } \\
10\end{array}$ & $52,94 \%$ & $82,35 \%$ & $29,41 \%$ \\
\hline 2 & Meniru angka 1 sampai 10 & $47,05 \%$ & $76,47 \%$ & $29,42 \%$ \\
\hline 3 & $\begin{array}{l}\text { Menghubungkan atau } \\
\text { memasangkan angka dengan } \\
\text { benda-benda sampai 10 }\end{array}$ & $35,29 \%$ & $64,70 \%$ & $29,41 \%$ \\
\hline 4 & $\begin{array}{l}\text { Mebilang dengan menunjuk } \\
\text { benda (mengenal konsep } \\
\text { angka dengan benda-benda) } \\
\text { sampai 10 }\end{array}$ & $41,17 \%$ & $88,23 \%$ & $47,06 \%$ \\
\hline 5 & $\begin{array}{l}\text { Menunjuk urutan benda } \\
\text { untuk bilangan sampai 10 }\end{array}$ & $47,05 \%$ & $94,11 \%$ & $47,06 \%$ \\
\hline 6 & $\begin{array}{l}\text { Membuat urutan angka 1 } \\
\text { sampai 10 dengan benda }\end{array}$ & $\mathbf{3 5 , 2 9 \%}$ & $\mathbf{7 0 , 5 8 \%}$ & $35,29 \%$ \\
\hline \multicolumn{2}{|c|}{ Rata-rata } & $\mathbf{4 3 , 1 3 \%}$ & $\mathbf{7 9 , 4 0 \%}$ & $\mathbf{3 6 , 2 7 \%}$ \\
\hline
\end{tabular}

Pada tabel 4.3 di atas dapat dilihat bahwa adanya peningkatan dari siklus I dan siklus II. Indikator keberhasilan kegiatan I menunjuk angka 1 sampai 10 pada siklus I mencapai 52,94 \% sedangkan pada siklus II mecapai 82,35\% dan terjadi peningkatan sebesar 29,41\%. Kegiatan II meniru angka 1 sampai 10 indikator keberhasilan pada siklus I mencapai 47,05 \% sedangkan pada siklus II mencapai $76,47 \%$ dan terjadi peningkatan sebesar $29,42 \%$. Kegiatan III menghubungkan atau mmemasangkan angka dengan benda-benda sampai 10 indikator keberhasilan pada siklus I mencapai 35,29 \% sedangkan pada siklus II mencapai 64,70\% dan terjadi peningkatan sebesar $29,41 \%$. Kegiatan IV membilang dengan menunjuk benda sampai 10 indikator keberhasilan pada siklus I mencapai 41,17\% sedangkan pada siklus II mencapai 88,23\% dan terjadi peningkatan sebesar 47,06 \%. Kegiatan $\mathrm{V}$ menunjuk urutan benda untuk bilangan sampai 10 indikator keberhasilan pada siklus I mencapai 47,05 \% sedangkan pada siklus II mencapai 94,11\% dan terjadi peningkatan sebesar 47,06 \%. Kegiatan VI membuat urutan angka 1 sampai 10 dengan benda indikator keberhasilan pada siklus I mencapai 35,29 \% sedangkan pada siklus II mencapai $70,58 \%$ dan terjadi peningkatan sebesar 35,29\%.

\footnotetext{
${ }^{9}$ Tabel 4.3. Perbandingan hasil observasi siklus I dan siklus II peningkatan kemampuan kognitif pada anak kelompok a melalui permainan pecah telur.
} 
Presentase hasil observasi siklus I secara keseluruhan mencapai 43,13\%. Sedangkan presentase hasil observasi siklus II meningkat menjadi 79,40\%. Presentase hasil observasi pada siklus I dan siklus II mempunyai selisih 36,27 \%.

Hasil penelitian yang dilakukan di atas bahwa pembelajaran kognitif menggunakan permainan pecah telur pada anak kelompok A dapat meningkatkan kemampuan anak dalam mengenal konsep bilangan, hal ini dapat dilihat dari penerapan permainan pecah telur pada siklus I dan siklus II. Peningkatan kemampuan anak dalam mengenal konsep bilangan tersebut dapat ditandai dengan adanya permainan pecah telur membuat anak merasa gembira untuk melakukan kegiatan berhitung, perkembangan kognitif anak berkembang secara optimal, khususnya kemampuan anak dalam mengenal konsep bilangan, dan penerapan permainan pecah telur pada kelompok A dapat meningkatkan kualitas proses pembelajaran.

Setelah diterapkan permainan pecah telur pada anak kelompok A pada siklus I ada peningkatan yang terjadi pada anak namun, masih belum mencapai indikator keberhasilan yang diharapkan. Maka peneliti melanjutkan kegiatan pembelajaran siklus II dengan melakukan kegiatan yang sama dan permainan yang sama namun, pada 2 bagian permainan pecah telur terdapat perbedaan warna agar anak menyatukan 2 bagian permainan pecah telur dengan cara dihitung karena pada siklus I 2 bagian permainan pecah telur mempunyai warna yang sama, sehingga anak menyatukan 2 bagian permainan pecah telur dengan persamaan warnanya.

Kegiatan ini dilakukan selama 6 hari atau 6 kali pertemuan dengan kegiatan yang bervariasi. Setelah kegiatan siklus II sudah dilaksanakan terjadi peningkatan terhadap kemampuan kognitif anak yaitu pada kegiatan menunjuk angka 1 sampai 10, meniru angka 1 sampai 10, menghubungkan atau memasangkan angka dengan benda-benda sampai 10, membilang dengan menunjuk benda sampai 10, menunjuk urutan benda untuk bilangan sampai 10, membuat urutan angka 1 sampai 10 dengan benda yang menggunakan permainan pecah telur. Jadi terdapat peningkatan pada kemampuan kognitif pada anak kelompok A melalui kegiatan bermain permainan pecah telur.

Perbedaan antara siklus I dan siklus II terdapat pada bentuk, warna dan tata letak gambar angka dan gambar alat kommunikasi media pembelajaran permainan pecah telur yaitu pada siklus I bentuk permainan pecah telur bulat sempurna, pada 2 bagian permainan pecah telur terdapat warna yang sama, tata letak gambar angka terdapat pada sisi kiri permainan pecah telur dan gambar alat komunikasi terdapat pada sisi kanan permainan pecah telur. Sedangkan pada siklus II bentuk permainan pecah telur agak menyerupai bentuk telur dengan agak loncong dibagian atas dan bulat dibagian bawah, pada 2 bagian permainan pecah telur terdapat warna yang berbeda, tata letak gambar angka terdapat pada sisi atas permainan pecah telur dan gambar alat komunikasi terdapat pada sisi bawah permainan pecah telur. Sehingga hasil yang tercapai semakin membaik. 
Berasarkan hasil penelitian tersebut dan dari hasil observasi keseluruhan pada siklus I dan siklus II dapat meningkatkan kemampuan kognitif anak kelompok A melalui permainan pecah telur. Hal ini dapat dilihat dari perolehan hasil keseluruhan rata-rata dengan prosentase $43,13 \%$ pada siklus I mencapai prosesntase $79,40 \%$ pada siklus II. Hasil akhir rata-rata peningkatan antar kedua siklus mencapai $36,27 \%$ termasuk kriteria penilaian sedang dalam penerapan permainan pecah telur pada pembelajaran kognitif anak usia dini.

\section{SIMPULAN DAN SARAN}

Berdasarkan hasil penelitian tentang peningkatan kemampuan kognitif pada anak kelompok A melalui permainan pecah telur dapat disimpulkan bahwa Kegiatan bermain permainan pecah telur dapat meningkatkan kemampuan kognitif pada anak kelompok A. Hal ini dapat dilihat dari presentase hasil observasi keseluruhan pada siklus I yang meliputi: menunjuk angka 1 sampai 10, meniru angka 1 sampai 10, menghubungkan atau memasangkan angka dengan bendabenda sampai 10, membilang dengan menunjuk benda sampai 10, menunjuk urutan benda untuk bilangan sampai 10, membuat urutan angka 1 sampai 10 dengan benda mencapai 43,13\% kemudian meningkat pada siklus II menjadi 79,40 \%. Permainan pecah telur dapat diterapkan dengan tiga cara yaitu: bermain bersama, kelompok dan individu.

Hasil kesimpulan, terdapat saran yang dapat digunakan bagi guru-guru Raudlatul Athfal untuk meningkatkan kemampuan kognitif pada anak kelompok A hendaknya guru menambahkan media pembelajaran seperti permainan pecah telur yang bisa dibuat sendiri sesuai kreasi masing-masing dan mudah dimainkan oleh anak. Bagi kepala sekolah Raudlatul Athfal, untuk meningkatkan kemampuan kognitif pada anak kelompok A hendaknya kepala RA memberikan dukungan berupa adanya sarana prasarana seperti media pembelajaran yang dapat meningkatkan semua aspek perkembangan anak. Disarankan untuk peneliti yang lain dapat menggunakan permainan pecah telur untuk meningkatkan aspek perkembangan lainnya seperti bahasa, fisik-motorik, sosial-emosional, dan lain sebagainya.

\section{DAFTAR RUJUKAN}

Arikunto,. S. (2002). Prosedur Penelitian. Jakarta : Rineka Cipta.

Asmawati,. L. (2014). Perencanaan Pembelajaran PAUD. Bandung : Remaja Rosdakarya.

Fadlillah,. M. (2017). Bermain Dan Permainan Anak Usia Dini. Jakarta : KENCANA.

Fadlillah,. M. (2014). Desain Pembelajaran PAUD: Tinjauan Teoretik dan Praktik. Jogjakarta : Ar Ruzz Media. 
Kustandi,. C, (2013). Media Pembelajaran Manusia dan Digital. Bogor : Ghalia Indonesia.

Mansur (2014). Pendidikan Anak Usia Dini Dalam Islam. Yogyakarta : Pustaka Belajar.

Sari,. R.P. (2017). Buku Ajar Perkembangan Kognitif Anak Usia Dini. Malang : IAI AL-Qolam.

Sugiyono (2016). Metode Penelitian Kuantitatif, Kualitatif, dan R\&D. Bandung : Alfabeta.

Sujiono,. A. (2011). Pengantar Statistik Pendidikan. Jakarta : Rajawali Press.

Wardhani,. IGAK. (2014). Penelitian Tindakan Kelas. Jakarta : Universitas Terbuka. 